THNTREVISTA/舀NTERVIEW 


\section{SÉRGIO MEDEIROS}

Sérgio Medeiros é professor na Universidade Federal de Santa Catarina atuando junto ao Departamento de Língua e Literatura Vernáculas (DLLV/UFSC) e à Pós-Graduação em Estudos da Tradução e Pós-Graduação em Literatura. Tradutor, ensaísta e poeta, suas atividades se interligam. Tem se dedicado aos mitos indígenas, como se constata pelas pesquisas realizadas em sua formação. Mestre em Letras (Teoria Literária e Literatura Comparada) pela Universidade de São Paulo (1990) com o trabalho "O Dono dos Sonhos - Um estudo das narrativas do Indio Xavante JeroniTsawe" e doutor em Letras (Teoria Literária e Literatura Comparada) pela Universidade de São Paulo (1995), com pesquisa sobre os mitos jê, denominada "Os heróis Jê". Realizou estágio de pós-doutorado na Stanford University (2001) pesquisando o poema maia "Popol Vuh".

A obra do escritor viajante Visconde de Taunay (1843-1899) também tem merecido esforços de pesquisa de Medeiros, que trouxe ao cenário da literatura brasileira o conto "Ierecê a Guaná" (Iluminuras, 2000) e a preparação da edição Memórias, de Taunay. Sobre Taunay também construiu o ensaio $A$ formiga-leão e outros animais na Guerra do Paraguai.

Na produção poética, Medeiros escreveu os livros Mais ou menos do que dois (2001), Alongamento (2004), Totem \& Sacrifício (2007, edição bilíngue espanhol/português), O sexo vegetal (2009), Vegetal sex (2010, edição bilíngue inglês/português, publicada em New Orleans, EUA), Figurantes (2011), Totens (2012), O choro da aranha etc. (2013) e $O$ fim de tarde de uma alma com fome (poema dramático, 2015), muitos dos quais já traduzidos para o espanhol, inglês e italiano.

Como tradutor, verteu na íntegra para o português, PopolVuh (Iluminuras, São Paulo, 2007), finalista do Prêmio Jabuti em 2008; 
Novembro, de Gustave Flaubert; a coletânea De santos e sábios: escritos estéticos e políticos, de James Joyce traduzido com André Cechinel, Caetano Galindo e Dirce Waltrick do Amarante, Cartas a Nora, também de James Joyce em parceria com Dirce Waltrick do Amarante. De Lewis Carrol traduziu Algumas aventuras de Silvia e Bruno e Alice no Jardim de Infância.

A entrevista com Sérgio Medeiros focaliza, em particular, a sua tradução de Alice no jardim da infância, livro para infância de Lewis Carrol dedicado às crianças de 0 a 5 anos. Nada mais justo para comemorarmos os 150 anos de Alice no País das Maravilhas, cuja temática é Tradução de literatura infantil e juvenil.

Eliane Santana Dias Debus

Universidade Federal de Santa Catarina

\section{ENTREVISTA COM SÉRGIO MEDEIROS}

Cadernos de Tradução (CT): Para você qual é o papel do tradutor e o ato de traduzir?

Sérgio Medeiros (SM): O tradutor, tal como eu o imagino, é alguém que, em certas circunstâncias (estou pensando no meu próprio caso), pode acalentar a sadia pretensão de intervir no mercado editorial, lançando nele obras que estejam fora de circulação ou que sejam desconhecidas. Então, para mim, o ato de traduzir, encarado dessa perspectiva (a qual, enfatizo, é muito particular), é um gesto político.

CT: Como você considera o acolhimento do mercado editorial brasileiro em relação à tradução de livros de recepção infantil e juvenil? 
SM: Eu sempre atuei, como tradutor e autor, nessa área literária, foi ela que me abriu as portas. Minha primeira tradução publicada foi Algumas aventuras de Sílvia e Bruno, de Lewis Carroll, um livro que se esgotou e que agora vai ser finalmente reeditado. Então vejo o universo da literatura infantojuvenil como um campo próspero para a tradução, já que a produção literária estrangeira nessa área é muito vasta e importante, e merece ser trazida, em parte, para o leitor brasileiro.

CT: O que o levou a traduzirAlice no jardim de infância(2013), de Lewis Carroll?

SM: Como já afirmei antes, tenho apostado em obras desconhecidas, e essa era uma obra --The Nursery Alice em inglês -- que jamais havia sido publicada em português, se não estou enganado, até aquele momento. Por isso propus ao meu editor, Samuel León, a publicação desse livro, que é uma adaptação que o próprio Carroll fez de Alice no País das Maravilhas. O objetivo dele, aliás, bem-sucedido, era colocar a história ao alcance de crianças muito pequenas, de zero a cinco anos. Considero essa versão abreviada e simplificada do clássico inglês um texto muito inventivo e cheio de surpresas, e isso, é óbvio, contribuiu para tornar o trabalho de tradução ainda mais prazeroso.

CT: A sua tradução de Alice para os pequeninhos é de 2013, já havia uma expectativa em relação às comemorações dos 150 anos de Alice no País das Maravilhas em 2015? Conheces outras traduções para o português desta publicação?

SM: Sim, quando a tradução saiu já se falava aqui no Brasil desses 150 anos. Então nós quisemos nos adiantar, eu e a editora. Como disse antes, a obra não estava disponível em português. Mesmo 
na Inglaterra ela ficou meio esquecida, e só veio à tona para valer recentemente, por ocasião dessas comemorações.

CT: Alice no país das maravilhas, reescrito por Lewis Carroll entre os anos de 1889 e 1890, tem o leitor criança de zero a cinco anos como público alvo. Podemos dizer que o autor previa uma leitura compartilhada entre o adulto - leitor do código gráfico e a criança - leitora das palavras ouvidas? Na tradução quais as marcas desse diálogo que podem ser evidenciadas?

SM: Um dos aspectos mais interessantes dessa adaptação de Alice, que chamei em português de Alice no jardim da infância, é a possibilidade de a criança pequena manusear e brincar com o livro, entre outras razões porque as ilustrações originais foram nela colorizadas e se tornaram mais excitantes e chamativas. Além disso, o autor sugere que as crianças balancem o livro para fazer com que um determinado personagem - o coelho - trema de medo. É claro que isso só acontecerá plenamente se o adulto que estiver lendo a história para a criançaa incentivar ao mesmo tempo a transformar o livro num brinquedo, tal como o autor sugeriu que ela fizesse. Sendo assim, a leitura compartilhada é a grande chave do livro, desde que o adulto também seja, é claro, um pouco criança. Ele não pode ser apenas uma voz neutra, um mero leitor que lê em voz alta uma narrativa para alguém que ainda não sabe ler muito bem.

CT : O livro é composto de 14 pequenos capítulos, suas nomeações seguiram àquelas propostas por Carroll?

SM: Fiz uma tradução tão fiel quanto possível, ou seja, transpus para o português na íntegra o texto original, sem simplificá-lo nem acrescentar frases de minha autoria. Não expliquei nada, ofereci aos leitores o texto tal como ele é ou poderia ser em português hoje, segundo minha posição em relação ao estatuto da tradução fiel. 
CT: As vinte ilustrações coloridas de Sir John Tenniel colaboraram ou influenciaram de algum modo na escrita tradutória?

SM: Sim, influenciaram, pois as cores foram uma descoberta para mim - finalmente, pude ver que Alice usava meias azuis. As cores deram vivacidade ao livro, e isso certamente influiu no meu texto, que refletiu a festa das cores. Não dava para fugir disso.

CT: Como ocorreu o processo de editoração (revisão e de preparação do texto traduzido e o diálogo com as ilustrações) na tradução de Alice (um livro ilustrado)?

SM: A editora quis fazer um livro grande, foi uma escolha dela. Em inglês há edições em formatos menores com capa dura, são muito bonitas, mas a proposta brasileira me pareceu ideal para crianças. O livro "mole" funciona melhor, é naturalmente mais flexível. Eu impus uma condição: cada ilustração na edição nacional deveria estar no mesmo lugar que ela ocupa no texto original, e isso felizmente aconteceu. A revisão foi profissional, creio eu. Mas houve uma falha: o título original, The Nursery Alice, por alguma razão que não sei explicar, não apareceu nessa edição uma única vez. Isso me incomodou muito.

CT: Quais os princípios teóricos que norteiam a sua atividade de tradutor?

SM: Teóricos não me guiam exatamente, pois eu levo mais em conta o trabalho prático de outros tradutores. Não os elevo, porém, a modelos, e sim os vejo como exemplos possíveis de ousadia na área da tradução. Citaria dois poetas que são, cada um à sua maneira, tradutores que me inspiram e que me deixam também perplexo, fazendo-me refletir sobre a tarefa do tradutor: Haroldo de Campos, no Brasil, e Herberto Helder, em Portugal. 
CT: Qual o desafio de traduzir livros que têm como público alvo a criança?

$S M$ : A criança é uma abstração, a meu ver, e a linguagem infantil é uma hipótese de trabalho. Como tradutor, sei que devo evitar o "infantilismo", que é um maneirismo (ou uma caricatura) verbal de mau gosto. Aposto, por isso, numa linguagem que seja eficaz do ponto de vista literário, sem esquecer, porém, que ela será absorvida por leitores jovens, que têm uma prática da língua muito diferente da minha. $O$ tradutor deve encontrar então uma linguagem que soe bem tanto para ele quanto para o possível leitor de pouca idade, que é, como se sabe, muito inventivo e sedento de novidades semânticas e sonoras.

Recebido em: 19/08/2015 Aceito em: 01/10/2015 